\title{
New Directions in Rebel Governance Research
}

\author{
Cyanne E. Loyle, Kathleen Gallagher Cunningham, Reyko Huang and Danielle F. Jung
}

\begin{abstract}
Day to day governance of civilians is not solely the purview of states. Rulemaking, rule-enforcing, and goods and services provision are central components of governance, yet in many instances it is non-state actors who assume these functions. We advance the study of governance by rebel groups engaged in armed confrontation against state governments. We identify five key areas of research where the field of rebel governance is best poised to go: the study of multi-level governance, rebel use of self-constraining or hand-tying behaviors, synergy between institutional form and domestic legitimacy, the nuanced role of territorial control in governance, and short- and longer-term impacts of rebel governance on post-conflict outcomes. In each area, we draw attention to the lessons already learned, interrogate key assumptions in existing work, raise arguments that remain under- or uninvestigated, and focus on the next frontier in the exploration of rebel governance. Learning more about the ways that rebel groups govern informs our understanding of armed conflict and its resolution, as well as provides broader lessons about the study of governance.
\end{abstract}

n rural Philippines, promising students were given financial support to pursue further education outside their village (Rubin 2018, 166). In the region that later became Eritrea, more than 33,000 women learned to read during the "Illiteracy is our main enemy" campaign (Gottesman 1998; Pateman 1998). In Nepal, judges travelled to rural villages as a "mobile team" to consult with victims prior to trial in cases of domestic violence against women (Braithwaite 2015, 12). In mid-March 2020, a public health campaign in north-western Syria aimed to prevent the spread of COVID-19 (Furlan 2020).
In none of these cases were these programs and services provided by the state. Instead, the New People's Army (the armed wing of the Communist Party of the Philippines), the Eritrean People's Liberation Front, the Communist Party of Nepal-Maoists, and the Syrian Salvation Government (the governance arm of Hayat Tahrir al-Sham), respectively, spearheaded these efforts. In short, rebel organizations, perhaps best known for their violence, provided basic goods and services and worked to meet the needs of citizens.

The provision of public services such as education, health, and dispute-resolution mechanisms are typically

Cyanne E. Loyle (1) is Associate Professor of Political Science and International Affairs at Pennsylvania State University and a Global Fellow at Peace Research Institute Oslo (cloyle@psu.edu). Her research examines transitional justice, civil war, and rebel governance. She is co-creator of the Post-Conflict and During-Conflict Justice Datasets and co-founder of the Rebel Governance Network.

Kathleen Gallagher Cunningham is Professor in the Department of Government and Politics at the University of Maryland and Research Professor at Peace Research Institute Oslo (kgcunnin@umd.edu). She works on political violence, nonviolent resistance, secession, and civil war. She is the author of Inside the Politics of Self-Determination (Oxford University Press, 2014) and helps maintain the Rebel Governance Network.

Reyko Huang (1) is Associate Professor at the Bush School of Government and Public Service at Texas A\&M University (rhuang@tamu.edu). Her research examines armed conflict with a focus on rebel governance, rebel diplomacy, and rebel leadership. She is the author of The Wartime Origins of Democratization (Cambridge University Press, 2016).

Danielle F. Jung (D) is Associate Professor of Political Science at Emory University (danielle.jung@emory.edu). Her research focuses on understanding how legitimacy is built and decays, particularly via service provision and governance by non-state organizations, as well as elections in fragile states. She is co-author of Lynching and Local Justice: Legitimacy and Accountability in Weak States (Cambridge University Press, 2020). 
thought to be the purview of state governments. Nevertheless, empirically, non-governmental organizations, religious groups, criminal syndicates, and rebel groups all participate, to some extent, in these core components of governance. In the context of armed conflict, rebel groups stand out as being one of the most prominent non-state actors to participate in these behaviors. Research on governance by rebel groups during civil wars has drawn our attention to the ways in which armed non-state actors govern as a direct component of their challenge to the state (e.g., Arjona 2016; Arjona, Kasfir, and Mampilly 2015; Cunningham and Loyle 2021; Huang 2016a; Kasfir, Terpstra, and Frerks 2017; Mampilly 2011; Staniland 2014). This observation highlights a critical need to understand how, when, and why rebels take up governance functions; how they interact with the state and other providers as they do so; and the outcomes of such efforts for the welfare of ordinary citizens.

Rebel groups are organized non-state actors that challenge their host state through violent means in order to achieve a political objective. We center our attention on rebel groups as consequential actors in the global system in their own right; with violent conflicts within states continuing around the world, rebels demonstrate complex relationships with states, external supporters and adversaries, international organizations, other rebel actors, and civilian populations. We focus on rebel actors because of the inherently political nature of their governance claims as a direct challenge to state power.

In this article, we evaluate existing work on rebel governance, illuminating key contributions and building a bridge to scholarship on governance more broadly. To do so, we develop five arguments, each of which challenges common assumptions and understandings about rebel governance and offers new ways to conceptualize, theorize, measure, and analyze rebel governance. Our arguments, in brief, are as follows. First, rebel governance is not always zero-sum. Rather, it is often characterized by overlapping zones of control and even collaborative efforts by a variety of actors. Second, we argue that one way rebel groups amass more power is by giving up power, or more specifically, by creating institutions that tie their own hands. Institutions such as popular elections and referenda create risks for rebel groups, and yet they yield enough political benefits that many rebel groups choose to implement them. Third, it has become almost a truism that rebel groups seek legitimacy, and yet we identify reasons to further probe even this basic assumption. Rebel governance can boost legitimacy but can also jeopardize it, depending on civilian responses and other factors. Fourth, rebels can wield control over civilians without holding territory and govern without infrastructure. This is a departure from conventional understandings and yet, once freed of the territorial control assumption, significant theoretical and empirical room opens up for further research into rebel governance via a-territorial means. Finally, we contend that rebel governance has enduring impacts on societies, civilians, and state governance, and identify new ways to examine such impacts.

While these arguments are not centered on a single theme, they each address an area of key debate or a nascent research agenda that yields critical questions. We do not call for a paradigm shift in the study of rebel governance; instead, we advocate for a pluralistic approach moving forward, relaxing problematic assumptions in the existing literature and advancing a multifaceted exploration of new questions-involving new levels of analysis, actors, and scope conditions. In developing our five arguments, we pay particular attention to how new cases and methods can be brought to bear to explore novel questions and motivate innovative research agendas.

The study of rebel governance has important implications for the study of governance more broadly. In deepening our understanding of rebel governance, we gain new insights into why non-state actors provide goods and services and how non-state governance differs, whether in motivation, processes, or outcomes, from state governance. Research into rebel governance also has potential to yield new insights about the strategic use of governance by both states and non-state actors, the relationship between governance and local legitimacy, the relevance of territorial control for governance provision, and the effects of institutional design on governance outcomes. These issues are relevant for other governance providers, including NGOs, international NGOs, and corporations, all of which play a role in delivering basic services to communities around the world. A greater understanding of how and why armed non-state actors govern will advance the growing literature on types and styles of governance in a diversity of contexts.

\section{Argument 1: Governance Is Not Always Zero-Sum}

Foundational work in the field of rebel governance has focused almost exclusively on emblematic cases of wellorganized and highly structured rebel institutions (e.g., Arjona 2016; Kasfir 2005; Mampilly 2011). Given this focus, cases such as the NRM in Uganda, the LTTE in Sri Lanka, and the self-declared Republic of Somaliland have come to dominate our understanding of how rebel groups solidify legitimacy and control. In many ways, this work has replicated the state governance literature in looking for those rebel groups whose governance activities and outcomes most closely resembled that of states, achieving a maximalist conception of governance and control. We question the generalizability of findings from these cases. In particular, we challenge the utility of this maximalist conception by studying areas of multi-layered governance.

Exclusively studying strong and well-established governance structures by rebel groups has led to an overfocus on the "state-like" qualities of rebel governance (or lack thereof). Yet work on early state formation did not begin 
with the premise that rebels sought to resemble, imitate, or be states per se. Instead, the territorially defined sovereign state was seen as the project of a confluence of factors, from geo-political competition (Ertman 1997) to the rise of literacy and decline of religiosity (Anderson 1983). Of particular note, the period of Western state formation was characterized by diverse sets of actors with often overlapping areas of authority (Spruyt 1996). A laser focus on the most "state-like" rebels belies the diversity of actors and governance behaviors at play in conflict settings, and critically, limits the bounds of our collective inquiry about governance.

Implicit in many studies of armed conflict is the assumption that rebels and the government are engaged in a zero-sum conflict over governance (Ledwidge 2017), yet this need not be the case. The focal cases in the study of rebel governance reinforce this assumption through an emphasis on groups that maintain absolute authority in a particular territory. Given the variety of possible governance-providing actors, and the array of possible governing arrangements, we find the assumption of a single governing authority to be myopic, precluding many important questions.

If governance is creating order and shaping behavior (Weber 1946), governance need not come from the state or from any single actor. In addition to the state, security and the provision of goods and services can come from armed actors, such as rebel groups or criminal syndicates (e.g., Lessing 2020), non-state actors such as NGOs or religious organizations, or even other states. Given the range of actors potentially involved in governance, the quest for governance need not be zero-sum. Rather, there are likely competing and complementary sources of authority, legitimacy, and capacity within a given space and time (Ostrom 1990).

Individuals around the world live in a variety of governance contexts. On one extreme, following from the emblematic rebel governance cases are examples where the state has failed to provide governance and non-state actors, such as rebel groups, step into this void (e.g., Somalia and Somaliland). States, particularly in developing countries, provide security, goods and services to varying degrees (Cammett and MacLean 2014; MacLean 2017). There are therefore examples of weak states where the state outsources components of governance, such as the provision of health care or clean water, to international NGOs (Mayer and Phillips 2017). Further, alternative governing arrangements can include instances where one state provides governance over another state, as in the case of colonialism, informal empires, protectorates, or spheres of influence (Lake 2011). In other cases, the state and religious authorities co-provide governance, as in the case of Islamic law in Iran. The most common condition of governance for most citizens is therefore likely one of multilayered governance where states, armed actors, private entities, NGOs, and other sources of authority compete and cooperate to provide security, goods and services.

Advances in the study of rebel governance elaborate the multilayered environments in which actors govern (Staniland 2012). In the introductory essay to a special feature in Civil Wars, Kasfir, Frerks, and Terpstra (2017) detail the ways in which rebel groups, along with police, foreign interveners, and other actors, create a polycentric field of governance, complicating prior studies of governance during armed conflict. Stel's (2017) work in this feature debunks the zero-sum logic of governance in the case of the PLO in Lebanon and instead demonstrates a continuum of mediated governance.

These innovations in the study of rebel governance call us to question the impact of multilayered governance on the individuals who live in these complex regimes. For example, under what conditions does the presence of multiple sources of governance improve social welfare outcomes? Engaging the literature on market economies, could it be the case that competition over the provision of security or goods and services increases the quality of these goods? It is also possible that living under multiple forms of governance poses certain cognitive challenges for individuals. Does the possibility of "forum shopping" for governance increase or weaken individuals' sense of security? There are also broader questions for state building. For example, under what conditions is multilayered governance more or less stable than concentrating governance power solely with the state?

To answer these questions, the study of rebel governance needs new data collection efforts that are less statecentric in their conceptions and measures to better capture governance in multilayered environments. One approach, for example, might be to collect objective and attitudinal measures at the individual level that include qualitative life-history interviews to document what individuals have received from which provider and when. Other individual measures could include survey measures that capture welfare and attitudes toward various state and non-state governors. At other levels of analysis, studies should document governor and government quality and effort of governance as well as how the multiple layers of governance intersect. Often such measures are of the highest quality and most complete for states, but as research on rebel governance shows, that may reflect less the actual range of governance activities and more the existing data collection biases.

\section{Argument 2: Giving Up Power Sometimes Gives You More Power}

The literature on rebel governance centers on the benefits governance behaviors bring to the group, primarily in terms of increased local legitimacy, increased combat effectiveness, and improved information gathering. 
However, the variety of governance arrangements that exist in practice suggest that governance can constrain rebels as well as empower them. Critically, more governance does not directly translate to more power for rebel groups. Instead, some governance behaviors constrain rebels, putting limits on their war-fighting capacity in the short term.

The constraining effects of governance institutions is well studied for states (cf. literature on democratic and autocratic institutions, such as Geddes (2003), Weeks (2008), Putnam (1988)). The development of this constraining relationship is seen as essential to modern state development in Europe and beyond (Bendix 1980; Slater 2010). While work on rebel governance has acknowledged the back and forth negotiations occurring between civilians and rebels (cf. Arjona 2016), there is room to explore more directly when and how governance choices constrain rebels. Rebels can tie their own hands-much as states do-in a variety of ways, and some forms of this behavior are likely to be more or less durable.

We know that rebels can and do think strategically about allowing constraints on their behavior. For example, taking direct financial or military support from outsiders often comes with important conditions (Salehyan, Gladitsch, and Cunningham 2011) ${ }^{1}$ and thus shape rebel governance decisions (Huang and Sullivan 2020). Jo (2015) details how rebel groups make and keep legal agreements constraining their behavior. For example, some rebel groups allowed the International Committee of the Red Cross to visit detainees in compliance with the Geneva Conventions, signaling their willingness to abide by international law (Jo 2015, 184). Fazal and Konaev (2019) show that half of rebel groups signed a commitment to ban landmines when approached by Geneva Call, an NGO that promotes rebel group adherence to international humanitarian norms. In each of these examples, rebels chose to give up some power today for possible longer-term benefits.

Local governance institutions can play a similar role in tying rebel's hands. Mampilly and Stewart (2021) suggest there are a number of ways rebels integrate civilians into governance structures, such as through local councils in rebel-held areas, that can ultimately constrain rebel behavior. Breslawski (2021) demonstrates that the inclusiveness of rebel institutions varies depending on the cohesion of the local community pre-conflict, and that rebels are willing to constrain their direct power when they see civilian goals as more aligned with their own. Cunningham, Huang, and Sawyer (2021) highlight the use of popular elections by rebels, an institution classically associated with increased accountability. Sawyer, Bond, and Cunningham (2020) show that rebels that choose to employ electoral governance institutions are less likely to commit acts of sexual violence against civilians, a practice that has been associated with both strategic choice on the part of rebels (Cohen 2016) and lack of control of rank and file (Butler, Gluch, and Mitchell 2007). Rebels also act locally to codify regulations and provide legal order, sometimes directly to their detriment, when they must address wrongs perpetrated by their own soldiers (Loyle 2020).

In addition to establishing participatory institutions and legal order, rebel groups use referenda projects strategically, leveraging non-sanctioned democratic behavior to pressure the state. This is particularly the case for autonomy- and independence-seeking rebels, such as the 2017 independence referendum in Nagorno-Karabakh or the referendum for independence by the Anjouan People's Movement in Comoros in 1997 (Mendez and Germann 2018). These referenda can reveal the power behind such movements, but they can also constrain rebel actors when outcomes are not in perfect alignment with their preferences. Indeed, Balcells and Cunningham (2020) suggest that competition for power within independence movements is a driving force behind many referenda as actors seek to lock in positions of public support among the local community.

Work on rebel governance demonstrates that rebel groups are willing to give up power to stay in power, raising a number of unanswered questions. Foremost among these is the question of whether these constitute actual constraints versus "window dressing." Rebels may enact constraining behaviors without a true commitment to rule following, accountability, or civilian exercise of power. However, literature on international organizations suggests that the creation, maintenance, and continued adherence to constraining institutions and practices can change actors' preferences and behavior over time (cf. Martin 1994; Keohane and Martin 1995). Do these patterns apply to rebel groups? There are other important questions: When are governance constraints effective and what are their broader effects on vulnerable populations, such as women in conflict settings? How do the multiple potential audiences of their behavior respond to the use of constraining behavior? Is it useful to try to characterize rebel institutions the way we do states, focusing on democratic versus autocratic institutions and variations within them (Downing 1993; Weeks 2008) or perhaps focused on veto points (Tsebelis 2002)?

To answer these questions, we need new data collection and more in-depth studies of particular governance behaviors. Perhaps as a first step this work should include better conceptualization and measurement of effectiveness and of support from different audiences. Individual-level survey work, similar to Revkin (2021), is a promising avenue toward this end. In addition, interview and focus group data can gauge individual and small group dynamics. At the rebel group level, a more systematic measure of institutional variation and veto points will allow for better identification and comparability of institutions, as well as 
for theoretical advances in understanding how rebel institutions vary and relate to other constraints, including from the state.

\section{Argument 3: The Right to Rule Requires the Right Rules}

Research into the governance practices of rebel groups has primarily conceptualized governance as a path to legitimacy. Building on the early rebellion philosophies of Che Guevara and Mao Zedong, the literature ascribes governance institutions to those groups seeking to demonstrate capacity, arguing that establishing this capacity is important for winning over and ultimately pacifying the civilian population (see a discussion in Mampilly 2011). While a useful heuristic for examining those groups with long term state-like governance aspirations (cf. center-seeking groups; Stewart 2018), this framework overlooks other potential governance aims such as warfighting, information gathering, and social control. In other words, rather than an attempt to build legitimacy, as Guevara and Mao envisioned, rebel governance is also employed as a tool of coercion. While rebel groups wield force and often have a monopoly on the use of that force in a given territory, it is less clear when and how these groups derive legitimacy from the civilian population and the impact that legitimacy has on warfighting ends. If we refrain from assuming a positive relationship between rebel governance and legitimacy, the question becomes why do rebels seek to build legitimacy and what is the role of governance institutions in achieving that aim?

Legitimacy is a concept that captures the "beliefs that bolster willing obedience" (Levi, Sacks, and Tyler 2009). A legitimate rebel group has successfully harnessed these beliefs to be "the rightful wielder of power, maker and interpreter of rules or user of force and who thereby warrants support and compliance" (Podder 2017, 687). Although it is possible to rule through coercion, legitimacy makes governing easier and more effective (Tyler 2006). As legitimacy is often seen as zero sum, the focus within much of the rebel governance literature has been on the ability of rebel groups to undermine the legitimacy of the state in order to strengthen their own (Podder 2017). As Ledwidge writes, "It is the job of the insurgent to drain that [legitimacy] reservoir and refill it with his own capital" $(2017,18)$. Again, this view starts from the premise that legitimacy is both useful and central to a rebel group's warfighting aims.

New work on the topic of rebel legitimacy challenges this premise. To begin, not all rebel groups are legitimacyseeking. Groups that do not rely heavily on civilian support (Weinstein 2006) or those groups more focused on international backing (Coggins 2014) may forgo efforts to compel compliance from the civilian population and instead expend resources on "monitoring and enforcement" (Levi, Sacks, and Tyler 2009). It may be that there are costs associated with these legitimacy-building activities that the group is not willing to take on, or not willing to take on at a given point in time. Other groups, such as those with secessionist aims, may be interested in legitimacy but only among a certain population or in a particular spatial location. The decision of a rebel group to seek legitimacy is shaped by the need for civilian resources (Weinstein 2006), the group's mobilization efforts (Loyle 2021), as well as civilian demand for governance (Florea and Malejacq 2018).

While states derive legitimacy from international claims to sovereignty, rebel groups do not enjoy the same universal legitimizing principals (Huddleston and Loyle N.d.). Legitimacy-seeking rebel groups adopt a variety of tactics to achieve this aim. Most central to the study of rebel governance have been those groups that adopt governance structures to enhance legitimacy, such as the provision of goods and services (Huang 2016a) or the creation and enforcement of laws (Ledwidge 2017; Loyle 2021). Other legitimization strategies include mechanisms for hand tying (Jo 2015), civilian consultation (Jaskoski 2020), the use of referenda (Balcells and Cunningham 2020), and the codification of transparent rules through rebel constitutions (Reed, Sawyer, and Ventura 2019).

Given the variation in desire and tools for seeking legitimacy there are still disparities in terms of when these strategies result in support from the population. What characteristics of legitimacy-seeking behavior are most likely to produce the desired outcomes? Characteristics of state legitimacy, such as government performance, administrative competence and procedural fairness are likely to also impact citizens' views of rebel legitimacy. Rebel groups that deliver on their promises to provide social services and are deemed competent to deliver on future promises are more likely to be seen as legitimate (Flynn and Stewart 2018). For example, groups with arguably higher levels of legitimacy among the civilian population often have a degree of transparency and inclusion in their governing processes. The firdi baito-local courts run by the Tigray People's Liberation Front in Ethiopia-operated with a strong degree of local autonomy (Loyle 2020). The National Resistance Movement in Uganda incorporated a high level of civilian participation and democratic elections in the village committee system (Kasfir 2005). It may also be that civilians consider rebel leadership and governance structures co-opted from existing authority systems, such as tribal authorities or Sharia courts, to be more legitimate (Mukhopadhyay 2014).

Civilians have a role to play in this process both as the actors who grant legitimacy as well as a force that shapes the conditions under which that legitimacy will be conveyed (Dorff 2019). New work by Florea and Malejacq (2018) traces the demand side of rebel governance whereby under certain conditions civilians lobby for the creation of rebel institutions and service provisions. On 
occasion rebels are reluctant rulers responding to strong demand from the civilian population for the provision of governance despite other military priorities. For example, the CPN-Maoist in Nepal created their court structure as a direct response to the deficiencies of the state in creating law and order (Sivakumaran 2009). The PIRA in Northern Ireland are often credited with policing local crimes in response to pressure from the Nationalist community (Munck 1984). Rebel governance created at the behest of the civilian population is likely to be seen as more legitimate than are more top-down rebel projects.

Despite the advances on the question of legitimacy in the field of rebel governance, there is still more we need to know. We have yet to develop a clear understanding of when and why rebels seek legitimacy. Central to this is the question of when is legitimacy needed to fulfill warfighting aims? Cases such as the NRM in Uganda suggests that legitimacy-seeking is not solely the purview of secessionist groups nor is it solely born of revolutionary ideologies. International audiences likely have a role to play both in conferring legitimacy and shaping domestic claims to legitimacy (Coggins 2014, Jo 2015). Furthermore, new research is needed to explore the demands and agency of civilians in their complicated interactions with rebel governors around them. Levi, Sacks, and Tyler (2009) identify the concept of behavioral legitimacy that differentiates actual compliance from coercion or other forms of acceptance of an actor's rule. When do civilians willingly obey rebel leaders? The process of rebel rule is iterative and responsive so we should also expect behaviors and relationships to change over time (Mampilly and Stewart 2021).

Answering questions of legitimacy calls for the use of new research methodologies such as the use of survey data and survey experiments to learn more about the people living under rebel rule, the degree of civilian agency, and citizens' governance preferences. New techniques in natural language processing could shed light on the kinds of arguments used by members and organizations alike to make their appeals to legitimacy. Like work by Loyle and Bestvater (2019) cataloging the use of social media by rebel group leaders, advances in this area could lead to a greater understanding of the ways rebel groups appeal to the civilian population.

\section{Argument 4: You Don't Need Roads to Rule}

Existing studies largely view rebel control of territory as a necessary condition for rebel governance. Whether implicitly or explicitly, studies hold that physical control of land enables rebel groups to engage in the building of administrative and bureaucratic institutions, infrastructure, and social services. These governance engagements, in turn, allow rebel groups to exert authority over people who populate the territory. Hence territory enables control, and institutions and infrastructure enable governance.
Conversely, a lack of territorial control or a situation of contested territorial control should drive rebel groups to fight intensely to (re)gain territory so that they can (re) create order through governance. Control of physical space is thus seen as a prerequisite for rebels' exercise of local authority, and territorial expansion a sine qua non for rebels' success (Kasfir 2005; Kalyvas 2006; Anders 2020).

This view of territorial control mirrors the wider scholarship on state formation and statebuilding, which sees territory as central to the formation and strengthening of the state. The Weberian definition of the state specifically refers to a defined territory on which a government sits (Weber 1946), and building a state requires a ruler to become a "stationary bandit" who sets down roots in a given territory for more efficient resource extraction (Olson 1993). Likewise, European state formation was a byproduct of wars of conquest and territorial expansion (Tilly 1990), while a major challenge of African statebuilding was that states had difficulty extending their reach into peripheral regions (Herbst 2000, 2). State infrastructural power, according to Mann, is the "institutional capacity of a central state ... to penetrate its territories and logistically implement decisions" (1984, 113, emphasis added). State power, in other words, cannot be understood apart from a study of how the state reaches into, controls, and governs its territories.

As applied to rebel groups, however, an uncritical assumption of local control and governance as tied to land can be more constraining than revealing (cf. Rubin and Stewart N.d.). While territorial control remains a fundamental aspect of violent rebellion, rebels understand that survival often hinges critically on their ability to gain support from local civilians and external states. And while territorial control can certainly facilitate rebel governance, features of contemporary civil conflicts suggest there is much beyond territorial control that enables rebel groups to govern, foster social relations with civilians, and appeal for external support. These notions further suggest that today's violent conflicts take place in contexts that have changed dramatically in the contemporary era, and that our understanding of how armed rebels project authority and govern should be revised accordingly.

Here, we focus on four modes of rebel governance of civilians that are distinct from, and unencumbered by, rebels' degree of territorial control. First, today's rebel groups govern as much by occupying digital space as they do geographical space. Rebel groups are increasingly active on social media such as Twitter (Loyle and Bestvater 2019), broadcasting streams of messages that create and maintain a wide following in an online "imagined community" of sorts (Anderson 1983). While the effects of rebels' social media use have yet to be systematically analyzed, it is clear that rebel groups use social media for standard governance purposes including propaganda, selfpromotion, and public outreach, with messages aimed as 
much at international as local and domestic audiences (Blaker 2015; Jones and Mattiacci 2019; Loyle and Bestvater 2019). But rebel groups' use of the Internet goes beyond propaganda and communication; rebels have recourse to highly robust "virtual sanctuaries" that facilitate online financial transfers, recruitment, and clandestine planning and communication (Kilcullen 2006, 113). These new Internet-based modalities of rebel operations are not only often exceedingly difficult for the state to track and dismantle, they can also obviate the need for more traditional forms of governance infrastructure such as rebel-operated banks and TV stations-infrastructure that often require rebel control of territory and can be directly targeted by state forces.

Second, rebel groups often deliver social services via "on the spot" governance that requires neither firm territorial control nor significant investments in infrastructure. In Nepal, for example, the Maoist rebels dispatched mobile courts that traveled to villages to hear cases (International Commission of Jurists 2008, 8). In Benghazi and other Libyan towns, armed and unarmed opposition actors set up local committees to oversee food distribution, humanitarian aid, and other services in mere days following the start of mass protests against the Qaddafi regime in 2011. Within two weeks, the opposition had coalesced into the National Transitional Council (NTC). This rapid bottom-up organizing was enabled less by rebel territorial control—which was nascent and at best tenuous — but by the swift dissolution of local state authority along with the widespread defection of senior state officials to the opposition (Lacher 2020, 19-21). In other cases, rebel groups can co-opt state services or negotiate their way into the state governance structure, thus creating a hybrid governance system that reaches a wide swathe of the population. The Taliban has governed in this manner in recent years, leading one study to conclude that "the Taliban do not have to take territory to control it" (Jackson 2018, 25).

Third, rebel governance can be a-territorial at its top echelons when its administrative center or executive leadership is a political, rather than an infrastructural, creation. Governance is about more than providing services to local communities; it also involves establishing oneself as an authority and legitimating that claim to authority. When the NTC declared itself "the sole representative all over Libya" in early March of 2011, it was a hastily assembled governance body that could only claim weak control of some eastern towns (Lacher 2020, 21). ${ }^{2}$ Regardless, France responded within days to recognize the NTC as the sole legitimate representative of the Libyan people; other foreign governments soon followed. ${ }^{3}$ In addition to creating a political body, a rebel leadership can also boost its credentials by introducing conventional trappings of statehood such as flags, slogans, and insignia that collectively signal their claim to political authority over people (Mampilly 2011). Research finds that such performative acts do have effects on governance. The Tamil Tigers' use of symbols of legitimation during its war against Sri Lanka, for example, "not only consolidated its grip on the Northeast, but also engineered a level of support and compliance" from the local populace (Terpstra and Frerks 2018, 1001-1002).

Finally, rebel groups can govern from abroad, irrespective of their level of local territorial control. The top leader of the Free Aceh Movement (GAM), Hasan di Tiro, ran a self-styled government in exile in Sweden for almost the entire duration of the group's secessionist war against Indonesia (Aspinall 2009, 104-105). While GAM made governance efforts both locally and abroad, other rebel groups are more focused on external outreach (Tull 2005, 123). Many rebel groups maintain "diplomatic" wings in foreign capitals to oversee their external outreach efforts (Huang 2016b). If public outreach is an aspect of governance, these activities abroad, like rebel activism on social media, further reinforce the idea that rebel groups operate well beyond the confines of what local territory they may hold at any given time.

The question, then, is not whether territorial control is necessary for rebel governance, but what are the relative benefits and costs of governance within a physical space versus in cyberspace or through a political-administrative leadership that is not tied to territory? Such a research agenda would be consistent with the understanding that the locus of control has become increasingly detached from geographical space in recent decades for state and nonstate actors alike. What, then, does building roads do for rebels, in comparison to building a social media presence or a foreign presence? In what other ways do rebels capitalize on new technologies or foreign sanctuaries for governance purposes, and to what effects?

These questions broaden our understanding of rebel governance as a function not merely of physical control, but also of social, ideational, and technological control. Given the relative novelty of rebel use of cyberspace, there is ample room in future research for deep case study work, as well as innovative use of big data on rebels' internet and social media use, on the effects of technological control. Studies can also use social network analysis to map out rebel groups' nodes of contacts and bases abroad and examine how these networks enable war-fighting, governance, and legitimation. Paired with geo-spatial measures of the extent of territorial control, alternative measures of control will elucidate new theoretical insights.

\section{Argument 5: Where You Stood Determines Where You Now Sit}

Conflict institutions affect many long-term governance outcomes in post-conflict states, including the post-conflict rule of law (Loyle 2020), regime type (Huang 2016a), social cohesion (Kubota 2018), and health care systems (Ghobarah, Huth, and Russett 2003). However, many 
Table 1

Summary of arguments

\begin{tabular}{|c|c|c|c|}
\hline & New Areas of Inquiry & $\begin{array}{c}\text { Causal } \\
\text { Mechanisms }\end{array}$ & Data Collection Strategies \\
\hline $\begin{array}{l}\text { Argument 1: } \\
\text { Governance is } \\
\text { not always zero } \\
\text { sum }\end{array}$ & $\begin{array}{l}\text { - Impact of polycentricity and } \\
\text { multi-layered governance } \\
\text { - Stability of multi-layered gov- } \\
\text { ernance }\end{array}$ & $\begin{array}{l}\text { - Competition } \\
\text { - Outsourcing } \\
\text { and outbid- } \\
\text { ding } \\
\text { - Forum shop- } \\
\text { ping }\end{array}$ & $\begin{array}{l}\text { - Individual survey and focus } \\
\text { group data of citizens living } \\
\text { in multilayered environments } \\
\text { - Measures of government } \\
\text { and governance quality }\end{array}$ \\
\hline $\begin{array}{l}\text { Argument 2: Giving } \\
\text { up power } \\
\text { sometimes gives } \\
\text { you more power }\end{array}$ & $\begin{array}{l}\text { - When and how governance } \\
\text { choices constrain rebels } \\
\text { - Durability of constraints } \\
\text { - Identifying constraints versus } \\
\text { "window dressing" }\end{array}$ & $\begin{array}{l}\text { - Hand-tying } \\
\text { - Trade-offs } \\
\text { between } \\
\text { short-and } \\
\text { long-term } \\
\text { benefits }\end{array}$ & $\begin{array}{l}\text { - Individual survey and focus } \\
\text { group data of audience } \\
\text { response to constraining } \\
\text { behavior } \\
\text { - Catalogue of institutional } \\
\text { constraints or veto players } \\
\text { for rebel governance institu- } \\
\text { tions } \\
\text { - Better conceptualization and } \\
\text { measurement of government } \\
\text { effectiveness and support for } \\
\text { rebel governance }\end{array}$ \\
\hline $\begin{array}{l}\text { Argument } 3: \text { The } \\
\text { right to rule } \\
\text { requires the right } \\
\text { rules }\end{array}$ & $\begin{array}{l}\text { - Greater understanding of legit- } \\
\text { imacy-seeking behavior by } \\
\text { rebel groups and how govern- } \\
\text { ance institutions contribute to } \\
\text { legitimacy } \\
\text { - When and how does legitimacy } \\
\text { advance warfighting aims }\end{array}$ & $\begin{array}{l}\text { - Resource tra- } \\
\text { deoffs } \\
\text { between legit- } \\
\text { imacy and } \\
\text { coercion } \\
\text { - Governance } \\
\text { costs }\end{array}$ & $\begin{array}{l}\text { - During-conflict individual- } \\
\text { level data on governance } \\
\text { demands } \\
\text { - Measurement of civilian } \\
\text { agency under rebel rule }\end{array}$ \\
\hline $\begin{array}{l}\text { Argument 4: You } \\
\text { don't need roads } \\
\text { to rule }\end{array}$ & $\begin{array}{l}\text { - How do rebels exercise control } \\
\text { and authority } \\
\text { - A-territorial or international } \\
\text { rebel governance }\end{array}$ & $\begin{array}{l}\text { Benefits and } \\
\text { costs of terri- } \\
\text { torial versus a- } \\
\text { territorial con- } \\
\text { trol }\end{array}$ & $\begin{array}{l}\text { Data collection on alternative } \\
\text { methods of social control, } \\
\text { e.g social media } \\
\text { - Measures of social, idea- } \\
\text { tional, and technological } \\
\text { control }\end{array}$ \\
\hline $\begin{array}{l}\text { Argument 5: Where } \\
\text { you stood } \\
\text { determines } \\
\text { where you now sit }\end{array}$ & $\begin{array}{l}\text { - Long-term outcomes of rebel } \\
\text { governance }\end{array}$ & $\begin{array}{l}\text { - Learning } \\
\text { mechanisms } \\
\text { - Institutional } \\
\text { repertoire } \\
\text { - Expectations } \\
\text { and demand } \\
\text { - Leadership } \\
\text { experience }\end{array}$ & $\begin{array}{l}\text { - Documentation of the } \\
\text { experiences of citizens living } \\
\text { under rebel control } \\
\text { - Psychological profiles of } \\
\text { civilians under rebel control } \\
\text { - Individual surveys on post- } \\
\text { conflict governance expect- } \\
\text { ations, trust }\end{array}$ \\
\hline
\end{tabular}

open questions remain about the lasting impacts of rebel governance on societies, civilians, and state governance following conflict.

The rebel governance literature has been primarily focused on the drivers of rebel governance rather than its outcomes. Notable exceptions suggest that rebel governance can have long-term impacts on state institutions. Huang (2016a), for example, demonstrates that postwar regimes are deeply rooted in wartime rebel governance experience (cf. Slater 2020). Rickard and Bakke (N.d.) show that paramilitary reliance on informal systems of "punishment attacks" and vigilantism in Northern Ireland has had lingering effects on support for the judiciary and policing in Northern Ireland, even two decades after the Good Friday Agreement.

Rebel governance also shapes post-conflict representation. Many rebel institutions provide leaders and citizens with institutional experience and expertise that may help post-conflict societies recover more quickly. Loyle (2020) demonstrates the presence of learning mechanisms which transfer skills and expectations from rebel judiciaries to postconflict rule of law. Rebel elections and rebel participation in elections during conflict may make their transition to participating in the post-conflict political system smoother, and the establishment of coherent, organized political parties easier (Cunningham et al. 2021). Candidates who 
participated in rebel governance have a record to run on, leading to governance experience and potentially higher quality candidates. Early work into these questions highlights many interesting facets: Dresden (2017) argues that certain rebel capacities will translate more easily into postconflict political competition, while Zaks (2021) examines under what conditions rebel structures better enable rebel group-to-political party transitions. On the other hand, Stam and Horowitz (2014) show that of all heads of state, those who are former rebels are the most likely to use force, potentially implying that politicians with former experience in rebel governance may behave differently than nonformer rebels.

The long-term effects of rebel governance-both for conflict dynamics and for individuals who have lived under rebel rule, or under dual-governance-are still poorly understood and leave many unanswered questions. For example, it is unclear how the process of post-conflict state-building will be affected by the experience of rebel governance. There is evidence that criminal governance complicates state-building (Bateson 2020; Jung and Cohen 2020; Moncada 2017), but the political nature of rebel governance may facilitate state-building if rebel governance institutions could be co-opted. While there is mounting evidence that civilians prefer harsh governance (by the state or the rebels) to ambiguous control (Revkin 2021), the long-term success of re-establishing robust institutions remains unclear.

Rebel governance offers scholars of governance an unusual view into civilian life under multiple regimes and institutions — often simultaneously—but we do not know yet what the psychological implications of these experiences are, for individuals or for society. Berry (2018) and Bauer et al. (2016) document the potentially transformational role of conflict on society-in generating social and political participation, particularly from previously marginalized members of society such as women. How does rebel governance strengthen or attenuate post-conflict post-traumatic growth or expectations around social engagement? How does it shape civilian assessments of the quality of governance, and expectations of the governed? Revkin shows that in Mosul these elements were critical to civilians' migration decisions (2021), but we know little about the long-term effects following conflict, and about how civilians adopt and re-adopt different views of citizenship and identity during periods where they experience different or layered governance.

To answer these questions the study of rebel governance must expand its data collection and theorizing, both at macro and micro levels. Archival and qualitative work on the historical roots of institutions can shed light on the institutional legacies of rebel governance. The effects of rebel governance will form a critical new piece of the statebuilding literature, which has often focused on the role of external states in the building process. Similarly, the role of rebel governance in transforming civilian life, particularly around core human rights like education, literacy, and health care is not fully understood (Jo 2015). At a micro-level, questions on the legacies of rebel governance for individuals should look more closely to innovations in surveys and experiments to understand within-person assessments and the psychological effects of rebel governance.

\section{Conclusion}

The phenomenon of rebel governance has generated a burst of scholarship in conflict studies in recent years. And yet there remains significant room for further study of how, when, and why armed non-state actors seek to govern civilian communities. In this article, we reflect on a generation of scholarship on rebel governance and identify five areas of inquiry, summarized in table 1 , which, if pursued, would help advance our understanding of rebel governance to a new level in the coming generation of scholarship.

These areas reflect the state of the rebel governance literature in parallel with the broader study of civil war and governance in the state-building tradition-two critical literatures from which rebel governance scholarship has grown. As scholarship on civil war emerged as distinct from work on social revolution, ${ }^{4}$ key assumptions from the study of international conflict took root, including the zero-sum nature of conflict and assumptions about rebel actors as solely aggressive power-seekers vying for territory and control. Earlier work on rebels as governors leans heavily on how such actors mimic and aspire to statehood, which led to an overfocus on territorial control and the ways in which state-like actors maintain legitimacy. The final argument brings rebel governance forward in time to the post-conflict environment, connecting this work to governance studies inside and outside the state-building tradition. Collectively, the five arguments urge a reconsideration of some of the most fundamental aspects of rebel governance, including its relationship to state governance, its institutional design, the role of legitimacy, its relation to physical territory, and its post-conflict legacies.

In addition to these five arguments, another way to bring the research agenda forward is to focus on causal mechanisms. For example, what explains why some rebel groups are more legitimacy-seeking than others, why some rebel groups embrace hand-tying institutions and others do not, and why some rebels prioritize local territorial control while others opt for extraversion? While existing work has identified organizational features and rebels' concern for international support, new work would likely also be enriched by established theories, including theories of collective action (e.g., use of selective incentives to gain civilian compliance), bargaining (between rebels and civilians), deterrence (of rebel defection), signaling (of future intent), cheap talk (via social media), and historical legacies (for understanding post-conflict trajectories). In other 
words, theories developed elsewhere in political science offer much utility for understanding rebel behavior. In turn, exploiting these theories helps to better incorporate rebel scholarship into the rest of political science, in lieu of building a "rebel research" silo.

Advancing our understanding of rebel governance has broader implications for how we tackle some of the most pressing social issues of the day, including the need for crucial services such as public health and education, as identified earlier. The United Nations, for example, continues to identify education as a critical component of development, including education indices as a key part of the Millennium Development Goals. Between 2005 and 2015 , over $\$ 120$ billion (US) was spent to promote education globally. ${ }^{5}$ The United States alone has devoted $\$ 11.2$ billion in 2020 to increasing global health outcomes, the vast majority provided bilaterally (state to state). ${ }^{6}$ These initiatives are predicated on the idea thatparticularly in times of conflict-the state is the only, or at least the primary, provider of governance on the ground. In challenging that idea, the research agenda put forward here opens space for an exploration of how rebel governance intersects with these global initiatives, as well as the implications of different rebel governance experiences on the ability of a variety of actors to meet these challenges.

\section{Acknowledgement}

The authors would like to acknowledge support from the Ostrom Workshop at Indiana University for hosting their program on Rebel Governance in May 2019, along with workshop attendees Jessica Braithwaite, R. Joseph Huddleston, Michael Rubin, and Megan Stewart.

\section{Notes}

1 Salehyan, Gleditsch, and Cunningham 2011 note the Contras relationship with their sponsor (the United States) as a prime example of this (716).

2 https://www.news.com.au/world/ferocious-battles-inlibya-as-national-council-meets-for-first-time/newsstory/77a9c3d6f7ffdb00ee111056a8447ac8.

3 https:/www.nytimes.com/2011/03/11/world/ europe/ 11 france.html.

4 See Barbara Walter's 1997 influential study.

5 Global Education Monitoring Report 2019. "Migration, displacement and education: building bridges, not walls." UNESCO (https://en.unesco.org/gem-report/ report/2019/migration).

6 Via USAID. "Breaking Down the U.S. Global Health Budget by Program Area," KFF, March 12, 2020 (https://www.kff.org/global-health-policy/fact-sheet/ breaking-down-the-u-s-global-health-budget-byprogram-area/).

\section{References}

Anders, Therese. 2020. "Territorial Control in Civil Wars." Journal of Peace Research 57(6): 701-14.

Anderson, Benedict. 1983. Imagined Communities. London: Verso.

Arjona, Ana. 2016. Rebelocracy: Social Order in the Colombian Civil War. New York: Cambridge University Press.

Arjona, Ana, Nelson Kasfir, and Zachariah Mampilly, eds. 2015. Rebel Governance in Civil War. New York: Cambridge University Press.

Aspinall, Edward. 2009. Islam and Nation. Stanford, CA: Stanford University Press.

Balcells, Laia, and Kathleen Cunningham. 2020. "The Strategic Use of Self-Rule Referendums." Presented at International Studies Association Annual Meeting, Honolulu. HI. March 25-28, conducted remotely.

Bateson, Regina. 2020. "The Politics of Vigilantism.” Comparative Political Studies. 54(6): 923-55.

Bauer, Michal, Christopher Blattman, Julie Chytiov, Joseph Henrich, Edward Miguel, and Tamar Mitts. 2016. “Can War Foster Cooperation?" Journal of Economic Cooperation 30(3): 249-74.

Bendix, Reinhard. 1980. Kings or People: Power and the Mandate to Rule. Berkeley: University of California Press.

Berry, Marie. 2018 War, Women, and Power: From Violence to Mobilization in Rwanda and Bosnia-Herzegovina. Cambridge: Cambridge University Press.

Blaker, Lisa. 2015. “The Islamic State's Use of Online Social Media.” Military Cyber Affairs 1(1). (https:// digitalcommons.usf.edu/cgi/viewcontent.cgi? referer $=\&$ httpsredir $=1 \&$ article $=1004 \&$ context $=\mathrm{mca}$ ).

Braithwaite, John. 2015. "Gender, Class, Resilient Power: Nepal Lessons in Transformation." RegNet Research Paper 2015/92. https://doi.org/10.2139/ssrn.2685495

Breslawski, Jori. 2021. "The Social Terrain of Rebel Held Territory.” Journal of Conflict Resolution. 65(2-3): 453-79.

Butler, Christopher K., Tali Gluch, and Neil J. Mitchell. 2007. "Security Forces and Sexual Violence: A CrossNational Analysis of a Principal-Agent Argument." Journal of Peace Research 44(6): 669-87.

Cammett, Melani, and Lauren M. MacLean, eds. 2014. The Politics of Non-State Social Welfare. Ithaca, NY: Cornell University Press.

Cohen, Dara Kay. 2016. Rape during Civil War. Ithaca, NY: Cornell University Press.

Coggins, Bridget. 2014. Power Politics and State Formation in the Twentieth Century: The Dynamics of Recognition. Cambridge: Cambridge University Press 
Cunningham, Kathleen Gallagher, Reyko Huang, and Katherine M. Sawyer. 2021. "Voting for Militants: Rebel Elections in Civil War." Journal of Conflict Resolution 65(1): 81-107.

Cunningham, Kathleen Gallagher, and Cyanne E. Loyle. 2021. "Introduction to the Special Feature on Dynamic Process of Rebel Governance." Journal of Conflict Resolution 65(1): 3-14.

Dorff, Cassy. 2019 "Violent and Nonviolent Resistance in Contexts of Prolonged Crisis: The Civilian Perspective."

Journal of Global Security Studies 4(2): 286-91.

Downing, Brian. 1993. The Military Revolution and Political Change: Origins of Democracy and Autocracy in Early Modern Europe. Princeton, NJ: Princeton University Press.

Dresden, Jennifer Raymond. 2017. "From Combatants to Candidates: Electoral Competition and the Legacy of Armed Conflict." Conflict Management and Peace Science 34(3): 240-63.

Ertman, Thomas. 1997. Birth of the Leviathan: Building States and Regimes in Medieval and Early Modern Europe. Cambridge: Cambridge University Press

Fazal, Tanisha M., and Margarita Konaev. 2019. "Homelands versus Minelands: Why Do Armed Groups Commit to the Laws of War?" Journal of Global Security Studies 4(2): 149-68.

Florea, Adrian, and Romain Malejacq. 2018. "The Demand and Supply Side of Rebel Governance." Presented at the Network of European Peace Scientists Annual Conference, Verona, Italy. June 18-20.

Flynn, D. J., and Megan A. Stewart. 2018. "Secessionist Social Services Reduce the Public Costs of Civilian Killings: Experimental Evidence from the United States and the United Kingdom.” Research \& Politics 5(40). https://doi.org/10.1177/2053168018810077

Furlan, Marta. 2020. "Rebel Governance at the Time of COVID-19: Emergencies as Opportunities for Rebel Rulers." Studies in Conflict \& Terrorism. DOI: 10.1080/1057610X.2020.1816681

Geddes, Barbara. 2003. Paradigms and Sand Castles: Theory Building and Research Design in Comparative Politics. Ann Arbor: University of Michigan Press.

Ghobarah, Hazem Adam, Paul Huth, and Bruce Russett. 2003. "Civil Wars Kill and Maim People_-Long after the Shooting Stops." American Political Science Review 97(2):189-202.

Gottesman, Leslie. 1998. To Fight and Learn: The Praxis and Promise of: iteracy in Eritrea's Independence War. Trenton, NJ: Red Sea Press.

Herbst, Jeffrey. 2000. States and Power in Africa. Princeton, NJ: Princeton University Press.

Huang, Reyko. 2016a. The Wartime Origins of Democratization: Civil War, Rebel Governance, and Political Regimes. Cambridge: Cambridge University Press.
—. 2016b. "Rebel Diplomacy in Civil War." International Security 40(4): 89-126.

Huang, Reyko, and Patricia Sullivan. 2020. “Arms for Education? External Support and Rebel Social Services." Journal of Peace Research. https:// doi.org/10.1177\%2F0022343320940749

Huddleston, R. Joseph, and Cyanne E. Loyle. N.d. "Right and Proper: New Questions on State Legitimacy from the Rebel Governance Literature." Unpublished manuscript.

International Commission of Jurists. 2008. "Nepal: Justice in Transition.” February. (http://www.icj.org/ wp-content/uploads/2012/04/Nepal-Justice-inTransition-Thematic-reports-2008.pdf).

Jackson, Ashley. 2018. Life under the Taliban Shadow Government. Overseas Development Institute. (https:// odi.org/en/publications/life-under-the-talibanshadow-government/)

Jaskoski, Maiah. 2020. "Participatory Institutions as a Focal Point for Mobilizing: Prior Consultation and Indigenous Conflict in Colombia's Extractive Industries." Comparative Politics 52(4): 537-56.

Jo, Hyeran. 2015. Compliant Rebels. New York: Cambridge University Press.

Jones, Benjamin T., and Eleonora Mattiacci. 2019. "A Manifesto, in 140 Characters or Fewer: Social Media as a Tool of Rebel Diplomacy." British Journal of Political Science 49(2): 739-61.

Jung, Danielle F., and Dara Kay Cohen. 2020. Lynching and Local Justice: Legitimacy and Accountability in Weak States Cambridge Elements in Political Economy. Cambridge: Cambridge University Press.

Kalyvas, Stathis. 2006. The Logic of Violence in Civil War. Cambridge: Cambridge University Press.

Kasfir, Nelson. 2005. "Guerrillas and Civilian Participation: The National Resistance Army in Uganda, 1981-86." Journal of Modern African Studies 43(2): 271-96.

Kasfir, Nelson, Georg Frerks, and Niels Terpstra. 2017. "Introduction: Armed Groups and Multi-layered Governance.” Civil Wars 19(3): 257-78.

Keohane, Robert O., and Lisa L. Martin. 1995. "The Promise of Institutionalist Theory." International Security 20(1): 39-51.

Kilcullen, David. 2006. "Counter-Insurgency Redux." Survival 48(4): 111-30.

Kubota, Yuichi. 2018. "Nonviolent Interference in Civic Life During Civil War: Rebel Service Provision and Postwar Norms of Interpersonal Trustworthiness in Sri Lanka." Security Studies 27(3): 511-30.

Lacher, Wolfram. 2020. Libya's Fragmentation: Structure and Process in Violent Conflict. London: I.B. Tauris.

Lake, David A. 2011. Hierarchy in International Relations. Ithaca, NY: Cornell University Press 
Ledwidge, Frank. 2017. Rebel Law: Insurgents, Courts and Justice in Modern Conflict. Oxford: Oxford University Press.

Lessing, Benjamin. 2020. "Conceptualizing Criminal Governance." Perspectives on Politics. FirstView. doi: 10.1017/S1537592720001243

Levi, Margaret, Audrey Sacks, and Tom Tyler. 2009. "Conceptualizing Legitimacy, Measuring Legitimating Beliefs." American Behavioral Scientist 53(3): 354-75.

Loyle, Cyanne E. 2020. "Laws and Order: The Impact of Rebel Governance on Post-Conflict Rule of Law." Presented at the Online Peace Science Colloquium, September 25.

—_. 2021. "Rebel Justice during Armed Conflict." Journal of Conflict Resolution 65(1): 108-34.

Loyle, Cyanne E., and Samuel E. Bestvater. 2019. “\#rebel: Rebel Communication Strategies in the Age of Social Media." Conflict Management and Peace Science 36(6): 570-90.

MacLean, Lauren M. 2017. "Neoliberal Democratisation, Colonial Legacies and the Rise of the Non-State Provision of Social Welfare in West Africa." Review of African Political Economy 44(153): 358-80.

Mampilly, Zachariah, and Megan A. Stewart. 2021. "A Typology of Rebel Political Institutional Arrangements." Journal of Conflict Resolution 65(1): 15-45

Mampilly, Zachariah Cherian. 2011. Rebel Rulers: Insurgent Governance and Civilian Life during War. Reprint ed. Ithaca, NY: Cornell University Press.

Mann, Michael. 1984. The Autonomous Power of the State. Oxford: Blackwell.

Martin, Lisa L. 1994. Coercive Cooperation: Explaining Multilateral Economic Sanctions. Princeton, NJ: Princeton University Press.

Mayer, Frederick W., and Nicola Phillips. 2017. "Outsourcing Governance: States and the Politics of a 'Global Value Chain World." New Political Economy 22(2): 134-52.

Mendez, Fernando, and Micha Germann. 2018

"Contested Sovereignty: Mapping Referendums on Sovereignty over Time and Space." British Journal of Political Science 48(1): 141-65.

Moncada, Eduardo. 2017. "Varieties of Vigilantism: Conceptual Discord, Meaning, and Strategies." Global Crime 18(4): 403-23.

Mukhopadhyay, Dipali. 2014. Warlords, Strongman Governors and State Building in Afghanistan. New York: Cambridge University Press.

Munck, Ronnie. 1984. "Repression, Insurgency, and Popular Justice: The Irish Case." Crime and Social Justice. 21/22: 81-94.

Olson, Mancur. 1993. "Dictatorship, Democracy, and Development." American Political Science Review 87(3): 567-76.
Ostrom, Elinor. 1990. Governing the Commons: The Evolution of Institutions for Collective Action. New York: Cambridge University Press.

Pateman, Roy. 1998. Eritrea: Even the Stones Are Burning. Trenton, NJ: Red Sea Press.

Podder, Sukanya. 2017. "Understanding the Legitimacy of Armed Groups: A Relational Perspective." Small Wars \& Insurgencies 28(4-5): 686-708.

Putnam, Robert D. 1988. "Diplomacy and Domestic Politics: The Logic of Two-Level Games." International Organization 42(3): 427-60.

Reed, William, Katherine Sawyer, and Tiago Ventura. 2019. "Have no Faith in Constitutions? The Content of Rebel Constitutions in Civil War." Presented at the Annual Meeting of the American Political Science Association, Washington, DC, August 29-September 1.

Revkin, Mara Redlich. 2021. "Competitive Governance and Displacement Decisions under Rebel Rule: Evidence from the Islamic State in Iraq." Journal of Conflict Resolution 65(1): 46-80.

Rickard, Kit, and Kristin Bakke. N.d. "Legacies of Wartime Order in Northern Ireland.” Working paper. (https:// www.kit-rickard.com/project/northern-ireland/).

Rubin, Michael. 2018. "Rebel Territorial Control, Governance, and Political Accountability in Civil War: Evidence from the Communist Insurgency in the Philippines." Journal of Conflict Resolution 64(2-3): 459-89.

Rubin, Michael E., and Megan Stewart. N.d. "Rebel Territorial Control and Governance." Unpublished manuscript.

Salehyan, Idean, Kristian Skrede Gleditsch, and David E. Cunningham. 2011. "Explaining External Support for Insurgent Groups.” International Organization 65(4): 709-44.

Sawyer, Katherine M., Kanisha Bond, and Kathleen Gallagher Cunningham. 2020. "Rebel Leader Ascension and Wartime Sexual Violence." Journal of Politics 83(1). (https://www.journals.uchicago.edu/doi/ abs/10.1086/709432).

Sivakumaran, Sandesh. 2009. "Courts of Armed Opposition Groups: Fair Trials or Summary Justice?" Journal of International Criminal Justice 7(3): 489-513.

Slater, Dan. 2010. Ordering Power. Cambridge: Cambridge University Press.

- 2020. "Violent Origins of Authoritarian Variation: Rebellion Type and Regime Type in Cold War Southeast Asia." Government and Opposition 55(1): 20-41

Spruyt, Hendrik. 1996. The Sovereign State and Its Competitors: An Analysis of Systems Change. Princeton, NJ: Princeton University Press.

Stam, Allan, and Michael Horowitz 2014. "How Prior Military Experience Influences the Future Militarized Behavior of Leaders." International Organization 68(3): 527-59. 
Staniland, Paul. 2012. "States, Insurgents, and Wartime Political Orders.” Perspectives on Politics 10(2): 243-64.

- 2014. Networks of Rebellion. Ithaca, NY: Cornell University Press.

Stel, Nora. 2017. "Mediated Stateness as a Continuum: Exploring the Changing Governance Relations between the PLO and the Lebanese State." Civil Wars 19(3): 348-76.

Stewart, Megan. 2018. "Civil War as State-Making: Strategic Governance in Civil War." International Organization 72(1): 205-26.

Terpstra, Niels, and Georg Frerks. 2018. "Governance Practices and Symbolism: De Facto Sovereignty and Public Authority in 'Tigerland."' Modern Asian Studies 52(3): 1001-42.

Tilly, Charles 1990. Coercion, Capital, and European States, AD 990-1990. Cambridge, MA: B. Blackwell.

Tsebelis, George. 2002. Veto Players: How Political Institutions Work. Princeton, NJ: Princeton University Press.
Tull, Denis M. 2005. The Reconfiguration of Political Order in Africa: A Case Study of North Kivu. Hamburg: Institut für Afrika-Kunde.

Tyler, Tom R. 2006. "Psychological Perspectives on Legitimacy and Legitimation." Annual Review of Psychology 57(1): 375-400.

Walter, Barbara F. 1997. "The Critical Barrier to Civil War Settlement." International Organization 51(3): 335-64.

Weber, Max. 1946. "Politics as Vocation." In From Max Weber: Essays in Sociology, ed. and trans. H.H. Gerth and C. Wright Mills, 77-128. New York: Oxford University Press.

Weeks, Jessica L. 2008. "Autocratic Audience Costs: Regime Type and Signaling Resolve.” International Organization 62(1): 35-64.

Weinstein, Jeremy. 2006. Inside Rebellion. Cambridge: Cambridge University Press.

Zaks, Sherry. 2021. "Resilience beyond Rebellion: How Today's Rebels Become Tomorrow's Parties.”. Presented at the University of Washington International Security Colloquium. January 22, remote transmission. 